\title{
Boosting the Employability of Students and Staff at European Higher Education Institutions: An Educational Framework for Entrepreneurship, Internationalisation and Innovation
}

\author{
Saulich, Christina ${ }^{a}$ and Lehmann, Tine ${ }^{b}$
}

${ }^{a}$ HTW Berlin Business School, Hochschule für Technik und Wirtschaft Berlin, Germany, ${ }^{\mathrm{b}}$ HTW Berlin Business School, Hochschule für Technik und Wirtschaft Berlin, Germany.

\begin{abstract}
Globalisation has altered the conditions of work and learning in Europe. Many European countries specialise in non-offshorable, knowledge- and skill-intensive tasks which require a highly educated workforce that is able to interact in global settings. European Higher Education Institutions (HEI) face the challenge of meeting the increased demand for skills of globalised work environments. In order to do this, HEI need to adapt their educational concepts. This involves promoting internationalisation, entrepreneurial and innovation skills. This paper aims to develop an educational framework for boosting student and staff employability at European HEI. It further adds to the practical dimension of HEI internationalisation, entrepreneurship education and innovation pedagogy by presenting an example how these interrelated concepts can be integrated into the curricula of HEI. At the methodological level this implies broadening traditional content-focused curricula and making use of active teaching methods that foster deep learning, best acquired in real work situations. Taking internationalisation serious further entails building up virtual learning networks and tapping the full potential of e-learning.
\end{abstract}

Keywords: employability, Higher Education Institutions, entrepreneurship education, innovation pedagogy, internationalization, globalisation 


\section{Introduction}

Globalisation has altered the conditions of work and learning. As a result of the increasing integration of production across borders many European companies specialise in nonoffshorable, knowledge- and skill-intensive business models to foster economic growth. The current labour market expects graduates and staff of Higher Education Institutions (HEI) to be equipped with the ability to interact in global settings as well as with specific international, intercultural, innovation, and entrepreneurship skills. This poses a challenge to the educational concepts of HEI which are expected to promote the employability of students and staff. Employability refers to a "set of skills, knowledge, understanding and personal attributes that make a person more likely to choose and secure occupations in which they can be satisfied and successful" (Dacre Pool \& Sewell, 2007, p.280). These attributes go beyond 'simply' holding a degree. This paper asks: How can HEI respond to the growing demand for entrepreneurship, innovation, and international skills induced by increasingly global work environments?

The aim of this paper is to develop an educational framework for boosting student and staff employability of HEI in Europe that addresses the needs of increasingly globalised, flexible, and uncertain work environments. It further seeks to add to the practical dimension of internationalisation, entrepreneurship education, and innovation pedagogy by presenting an example how these interrelated concepts can be integrated into the curricula of HEI.

The authors argue that boosting student and staff employability requires adapting the educational concepts of HEI. Internationalisation, entrepreneurial and innovation skills help HEI students and staff to excel in highly uncertain environments. This implies broadening traditional content-focused curricula and making use of teaching methods that foster deep learning (Bennet \& Bennet, 2008), best acquired through active methods and learning in real work situations. Incorporating internationalisation (Hénard, Diamond, \& Roseveare, 2012; Wit, Hunter, Howard, \& Egron-Polak, 2015), entrepreneurship education (e.g. Henry, Hill, \& Leitch, 2005a, Neck \& Greene, 2011) and innovation pedagogy (Kettunen, 2011; Kettunen, Kairisto-Mertanen, \& Penttilä, 2013) into HEI curricula is an important step towards establishing entrepreneurial universities (OECD \& EC, 2012).

This paper is structured as follows: The literature review in part two briefly introduces the concepts of entrepreneurial universities, internationalisation of HEI, entrepreneurship education and innovation pedagogy. It closes with an overview of the sets of skills these concepts aim to promote and the tools/methods that are most suitable to impart the latter. Part three proposes an educational framework for boosting student and staff employability at HEI. Part four gives an example for how this framework can be implemented at HEI using the example of the Erasmus+ Project "INTENSE - INTernational Entrepreneurship Skills Europe". The paper concludes by maping out avenues for future research. 


\section{Literature Review}

The concept of entrepreneurial universities emerged as a response to the changes within higher education triggered by globalisation. New technologies, an emerging knowledge economy and new funding conditions, inter alia, pose new demands on HEI in Europe and call for a redefinition of the purpose, the societal and economic role, and the structure of HEI. Entrepreneurial universities seek to foster entrepreneurship development in teaching and learning, university-business/external relationships for knowledge exchange, and internationalisation (OECD \& European Commission, 2012). These objectives are closely linked to the educational concepts of internationalisation, entrepreneurship education, and innovation pedagogy. The three concepts all seek to increase the employability of students and staff at HEI while focusing on different sets of skills and methods (s. table 1).

\subsection{Internationalisation of $\mathrm{HEI}$}

The internationalisation of HEI is understood as "a commitment, confirmed through action, to infuse international and comparative perspectives throughout the teaching, research and service missions of higher education." (Hudzik, 2011, p. 6) It has become an umbrella term whose implementation covers two dimensions: Internationalisation at home refers to enhancing international and intercultural skills of students at the domestic level by incorporating international and intercultural dimensions into curricula as well as teaching, research and extracurricular activities. Internationalisation abroad comprises educational activities across borders, such as distance learning, student and staff mobility, credit and degree mobility, establishing networks among students, scholars and institutions and offshore campuses (Altbach \& Knight, 2007; Wit et al., 2015). An important component of internationalisation is its virtual dimension, i.e. the use of information and communications technology (ICT) in education, offering students worldwide more and cheaper educational opportunities irrespective of their residence (Hénard et al., 2012).

\subsection{Entrepreneurship Education}

The vast strand of literature on entrepreneurship education (Valerio et al., 2014) has revealed two important findings: First, there is no overarching theory of entrepreneurship, hence, the skills attached to entrepreneurship remain contested. Secondly, the objectives, contents, and teaching approaches of entrepreneurship programmes at HEI vary greatly (Kratzer, Haase, \& Steiner, 2013). Entrepreneurship Education ranges from imparting entrepreneurial characteristics, raising awareness and teaching the process of setting-up and running a business to specific training for entrepreneurs, e.g. marketing or product 
development (Henry et al., 2005a). Although there is no common understanding of entrepreneurial skills, entrepreneurship education scholars seem to agree that entrepreneurship comprises task-oriented skills, e.g. for small business development and management, as well as behaviour-oriented skills, such as problem-solving, innovation, risk-taking and persistence (Henry et al., 2005a). There also seems to be agreement that at least some aspects of entrepreneurship (e.g. business management, technical management, marketing, etc.) can be taught at HEI (Henry et al., 2005b). Neck and Greene (2011, p. 57) argue that teaching entrepreneurship should be understood in terms of teaching a method (as opposed to a process with known inputs and outputs). Entrepreneurship as a method enables students to develop opportunities and implement activities in uncertain environments (Neck \& Greene, 2011).

\subsection{Innovation Pedagogy}

Innovation pedagogy was developed in Finland as a means to boost the employability of students, promote applied research, and to support regional development. It is rooted in constructivism and social learning theories which emphasise the learning effects of group interaction (Kettunen et al., 2013). Innovation pedagogy comprises five elements: 1) multifield interactions of different parties and organisational entities within inter-university network projects; 2) applied research that makes use of regional knowledge and networks; 3) flexible curricula to enable entrepreneurial and international activities; 4) entrepreneurship; and 5) internationalisation (Kettunen, 2011). Hence, innovation pedagogy provides a more holistic educational framework that includes entrepreneurship and internationalisation, however, it lacks a detailed approach to how the latter can be integrated into HEI curricula. The desired learning outcomes of innovation pedagogy encompass both, 'hard' knowledge related to the respective study-programmes and innovation competencies needed for innovation creating processes at the work place, understood as "a cluster of separate, at times overlapping, competences, capacities and skills, which all together can be regarded as innovation competence" (Watts, GarcíaCarbonell, \& Andreu-Andrés, 2013, p. 4). 
Table 1. Relevant Sets of Skills for Internationalisation, Entrepreneurship and Innovation

\begin{tabular}{|c|c|c|c|}
\hline & Internationalisation & Entrepreneurship & Innovation \\
\hline $\begin{array}{l}\text { Set of } \\
\text { skills }\end{array}$ & $\begin{array}{l}\text { - Intercultural skills } \\
\text { - Foreign language skills } \\
\text { - Global awareness } \\
\text { - Ability to interact in } \\
\text { global settings }\end{array}$ & $\begin{array}{l}\text { - Task-oriented skills: } \\
\text { small business develop- } \\
\text { ment and management } \\
\text { - Behaviour-oriented } \\
\text { skills: personal traits }\end{array}$ & $\begin{array}{l}\text { - Set of individual, inter- } \\
\text { personal and } \\
\text { networking skills } \\
\text { needed in innova-tion } \\
\text { creating processes }\end{array}$ \\
\hline $\begin{array}{l}\text { Tools/ } \\
\text { Methods }\end{array}$ & $\begin{array}{l}\text { - Intercultural trainings } \\
\text { - distance learning } \\
\text { - Student/staff mobilities } \\
\text { - Credit/degree mobility } \\
\text { - International networks } \\
\text { - Off-shore campuses }\end{array}$ & $\begin{array}{l}\text { - Entrepreneurship as a } \\
\text { method } \\
\text { - Active: learning by doing } \\
\text { - Practicing skills in real } \\
\text { life/work situations }\end{array}$ & $\begin{array}{l}\text { - } \text { Creating intra-HEI \& } \\
\text { regional networks } \\
\text { - Applied research } \\
\text { - Group interactions } \\
\text { - Entrepreneurial and } \\
\text { international activities }\end{array}$ \\
\hline
\end{tabular}

\section{Educational Framework}

While all of the three educational concepts discussed above aim to increase the employability of students - although their tools and methods remain generally vague - their individual scope and outreach are too narrow to meet the demands of globalised work environments. On the one hand, HEI need holistic educational concepts that equally impart internationalisation, entrepreneurship and innovation skills. On the other hand, this paper argues that it is crucial that educational concepts target students and staff of European Higher Education Institutions, e.g. through international staff trainings, (long-term) staff exchanges and collaborations with local and international external partners (European Commission, 2006).

The educational framework proposed in chart 1 illustrates the relationship between globalisation, the skills of HEI students and staff, and employability. Globalisation has changed work and learning environments. Globalised work environments in turn require specific sets of skills that go beyond content-related expertise in a specific field of study. In order to meet the growing demand for skills of globalised work environments, HEI need to become more entrepreneurial. This entails adopting an educational concept that promotes internationalisation, entrepreneurship and innovation skills of students and staff alike, thereby enhancing their employability. 
Chart 1. Education Framework: Boosting the Employability of HEI Students and Staff

\section{Globalised work and learning environment}

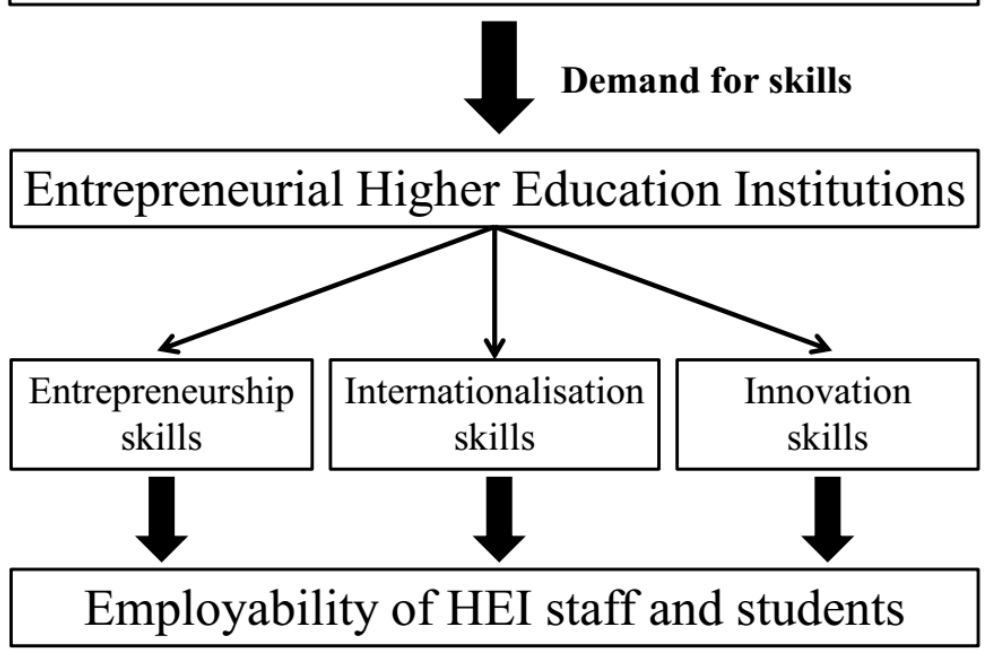

Source: the authors

\section{The Example of "INTENSE"}

Incorporating the different elements of this framework into the rigid curricula of HEI is a challenging task that requires financial and personnel resources and some creativity. The international project "INTENSE - INTernational Entrepreneurship Skills Europe" is currently being implemented across Europe ${ }^{1}$. The aim of INTENSE is to develop and implement a transnational teaching module on the internationalisation of small and medium-sized enterprises (SMEs) as an Open Educational Resource (OER). It involves establishing collaborations between HEI, HEI staff and students, SMEs, policy-makers and regional business associations. All participating HEI integrate the teaching module into their curricula.

INTENSE hereby follows the approach of innovation pedagogy, incorporating entrepreneurship education and internationalisation of HEI. 1) The project is designed multi-field, including HEIs with different core competences (entrepreneurship, project management, business, logistics), and regional networks by building national stakeholder

\footnotetext{
${ }^{1}$ Project lead: University of Applied Sciences (HTW) Berlin, GE. Project partners: Hoogeschool Utrecht, NL; University Colleges (UC) Leuven-Limburg, BE; University of Applied Sciences Turku, FI; J.J. Strossmayer University of Osijek, HR. Financed with the support of EU under Erasmus+.
} 
committees, including business associations and chambers. 2) It spurs applied research in the form of intellectual outputs, such as publications on learning results, an internationalisation toolkit for SMEs, a tool for assessing innovation skills, and policy recommendations. 3) INTENSE develops a module on "internationalisation of SMEs". This module is composed of different units which can be taught independently in order to ensure flexible curricular tailored to students' needs. 4) The module follows entrepreneurship education approaches by developing task oriented skills (business models of SMEs and internationalisation processes) and behaviour oriented skills (project management and consultancy skills). It further provides an opportunity for HEI learners to implement their knowledge in real work situations as they consult SMEs in their internationalisation process. 5) Finally, INTENSE supports the internationalisation of HEI at home by including internationalisation and intercultural aspects into curricula and abroad by establishing a transnational, virtual learning platform, collaborative e-learning tasks in international groups, trainings for students and staff, including a long-term staff exchange, and student and staff mobilities in the form of regular joint summer schools. The innovation competencies of HEI staff and students are measured before and after the project using the INCODE barometer.

The project increases the employability of students and staff as they gain deeper knowledge of entrepreneurship issues, international and intercultural experience, enhanced digital skills and an increased international professional network. HEI increase their international competitiveness and broaden their regional and international network.

\section{Conclusion}

Incorporating the educational concept of innovation pedagogy with a stronger focus on entrepreneurship education and internationalisation into the curricula of HEI is an important step towards becoming more entrepreneurial. The educational framework proposed in this paper contributes to the debate on how HEI can respond to the growing demand for skills induced by globalisation, in general, and on enhancing the employability of HEI students and staff, in particular. The INTENSE project served as an example for how this framework can be filled with life, however, this paper is limited to a theoretical framework and further research to empirically support its impact on employability is needed.

The methodological implications of integrating entrepreneurship education, innovation pedagogy and internationalisation into curricula at HEI provide an important avenue for future research. There is agreement in the literature that the skills related to these concepts have a strong 'arts' dimension that goes beyond teaching 'science', i.e. specific hard facts, through conventional pedagogical methods (Henry et al., 2005b). Understanding innovation, internationalisation and entrepreneurship as an art implies making use of active, learning-by-doing methods which relocate learning processes from the classroom to real 
work environments. What is more, taking internationalisation serious entails building up virtual learning networks and tapping the full potential of e-learning.

\section{References}

Altbach, P. G., \& Knight, J. (2007). The Internationalization of Higher Education: Motivations and Realities. Journal of Studies in International Education, 11(3-4), 290 305.

Bennet, D., \& Bennet, A. (2008). The Depth of Knowledge: Surface, Shallow or Deep? VINE, 38(4), 405-420.

Dacre Pool, L., \& Sewell, P. (2007). The Key to Employability: Developing a Practical Model of Graduate Employability. Education + Training, 49(4), 277-289.

European Commission. (2006). The Oslo Agenda for Entrepreneurship Education. Retrieved from http://www.gvpartners.com/web/pdf/EC_Oslo_Agenda.pdf

Hénard, F., Diamond, L., \& Roseveare, D. (2012). Approaches to InternationalisationApproaches to Internationalisation and Their Implications for Strategic Management and Institutional Practice. Paris. Retrieved from OECD website: https://www.oecd.org/edu/imhe/approaches\%20to\%20internationalisation\%20$\% 20$ final $\% 20-\% 20$ web.pdf

Henry, C., Hill, F., \& Leitch, C. (2005a). Entrepreneurship Education and Training: Can Entrepreneurship be Taught? Part I. Education + Training, 47(2), 98-111.

Henry, C., Hill, F., \& Leitch, C. (2005b). Entrepreneurship Education and Training: Can Entrepreneurship be Taught? Part II. Education + Training, 47(3), 158-169.

Hudzik, J. K. (2011). Comprehensive Internationalisation: From Concept to Action. Washington, DC. Retrieved from NAFSA website: http://www.nafsa.org/uploadedFiles/NAFSA_Home/Resource_Library_Assets/Publicati ons_Library/2011_Comprehen_Internationalization.pdf

Kettunen, J. (2011). Innovation Pedagogy for Universities of Applied Sciences. Creative Education, 02(01), 56-62.

Kettunen, J., Kairisto-Mertanen, L., \& Penttilä, T. (2013). Innovation Pedagogy and Desired Learning Outcomes in Higher Education. On the Horizon, 21(4), 333-342.

Kratzer, J., Haase, H., \& Steiner, S. (2013). Show Me the Money: The Impact of Funding on Entrepreneurship Education at German Universities. American Journal of Entrepreneurship, 6(2), 55-72.

Kulpa-Puczyńska, A. (2015). The model of cooperation with employers as the support measure for the development of entrepreneurial university potential. In E. de La Poza, J. Domènech, J. Lloret, M. C. V. Vela, \& E. Z. Agustí (Eds.), HEAd'15. 1st International Conference on Higher Education Advances (pp.326-333). Valencia. https://doi.org/10.4995/HEAd15.2015.435

Neck, H. M., \& Greene, P. G. (2011). Entrepreneurship Education: Known Worlds and New Frontiers. Journal of Small Business Management, 49(1), 55-70.

OECD \& European Commission. (2012). A Guiding Framework for Entrepreneurial Universities. Retrieved from https://www.oecd.org/site/cfecpr/ECOECD\%20Entrepreneurial\%20Universities\%20Framework.pdf 
Valerio, A., Parton, B., \& Robb, A. (2014). Entrepreneurship Education and Training Programs around the World: Dimensions for Success. Washington, DC. Retrieved from https://openknowledge.worldbank.org/bitstream/handle/10986/18031/9781464802027.p df

Watts, F., García-Carbonell, A., \& Andreu-Andrés, Á. (2013). Innovation Competencies Development: INCODE Barometer and User Guide. Turku. Retrieved from http://incode-eu.eu/uploads/media/ICB-Barometer.pdf

Wit, H. de, Hunter, F., Howard, L., \& Egron-Polak, E. (2015). Internationalisation of Higher Education. Brussels. Retrieved from European Parliament website: http://www.europarl.europa.eu/RegData/etudes/STUD/2015/540370/IPOL_STU(2015)5 40370_EN.pdf 